Thorax (1975), 30, 361.

\title{
A review of routine tests for respiratory viruses in hospital inpatients
}

\author{
N. C. OS W A L D, M. C. J O N E S, \\ and S. J. YEALLA ND \\ Brompton Hospital, London SW3 6HP
}

\begin{abstract}
Oswald, N. C., Jones, M. C., and Yealland, S. J. (1975). Thorax, 30, 361-366. A review of routine tests for respiratory viruses in hospital inpatients. During the period June 1967 to May 1972, viral tests were performed upon 1195 inpatients aged 12 and over in the Brompton Hospital. The overall diagnostic rate was $21.5 \%$, comparing $9.3 \%$ by isolation and $14.9 \%$ by complement fixation $(6.5 \%$ by four-fold rises in titre in paired sera, $8.4 \%$ by titres of $\geqslant 160$ in single sera). Only $42 \%$ of all patients had an acute respiratory illness within one week prior to admission, which seriously curtailed the chances of isolating viruses and of obtaining early serological specimens. The value of complement fixation tests on single specimens in the clinical management of patients is discussed. The profound effect of infections by influenza A on respiratory morbidity and hospital admission is stressed.
\end{abstract}

With the recent development of more rapid methods of viral identification, the time is opportune for reviewing the contribution of existing standard laboratory procedures to the identification of virus infections in patients with respiratory illness necessitating admission to hospital. Current practice requires that the diagnosis be based either on virus isolation or on the comparative results of complement fixation tests (CFTs) on paired acute and convalescent sera (Schmidt and Lennette, 1973). Experience suggests that these criteria of ten cannot be fulfilled as many patients are admitted after the acute phase of illness has passed, when virus excretion has declined or ceased (Griffin and Crawford, 1969) and acute sera are no longer available. In such patients much reliance must be placed upon CFT titres on single specimens. These aspects have been considered in the analysis of results obtained at Brompton Hospital over a five-year period.

\section{MATERIAL AND METHODS}

During the period June 1967 to May 1972, reports of viral tests upon 1195 inpatients aged 12 or over were recorded in the virus laboratory. These have been correlated with the hospital notes. There were 709 males and 486 females, of whom 565 $(47 \cdot 3 \%)$ were in the age group 50-69. The 1195 patients comprised $10 \cdot 7 \%$ of the 11126 medical admissions during the five-year period. Some 972 $(81.3 \%)$ started an acute respiratory illness within 28 days prior to admission to hospital and 502 $(42.0 \%)$ within seven days of admission. Acute respiratory illnesses were divided into influenzalike illnesses, upper respiratory infections, bronchitis, asthma, and pneumonia. Among the 972 patients with recent acute illness there were 324 with chronic bronchitis, 195 with asthma, and 139 with other chronic pulmonary diseases. In addition, 314 patients had no previous pulmonary disease and many of these were admitted with pneumonia and during outbreaks of influenza.

For virus isolation, upper respiratory secretions were inoculated routinely into primary rhesus monkey kidney, human diploid embryo lung fibroblast (WI 38), and human carcinoma (HEp2) cells. Neutralization tests were used for viral identification. Mycoplasma pneumoniae (M. pneumoniae) was isolated on a selective medium similar to that described by Chanock et al. (1967). Fortified Difco PPLO agar (Andrews, 1968) was also inoculated. Typing of mycoplasma was by the paper disc growth inhibition test (Clyde, 1964), using a micro method adapted from Bradstreet and Taylor (1962). Serologically, a four-fold or greater rise in titre by CFT in paired sera or a titre of $\geqslant 160$ on a single serum sample were regarded as evidence of 
recent infection. The laboratory provided a weekly service for CFT.

\section{LABORATORY RESULTS}

The results of laboratory tests are summarized in Table I. With 1089 tests, CFT titres on single specimens comprised the largest group. Retained serum was subsequently retested against second specimens in $393(36.1 \%)$ of these. There were 599 attempts at viral isolation.

Influenza A was isolated only in the winter months with a peak of 34 isolations during December 1969 to January 1970 when the Hong Kong epidemic was at its height. Eleven of the 12 cultures of $M$. pneumoniae were obtained during outbreaks in the winter of 1967-68 and in the latter months of 1971 . Herpes simplex virus (HSV) was isolated on 20 occasions; as it is probably not a primary respiratory pathogen, it has been excluded from the tables. No attempt was made to grow the agents of psittacosis and $Q$ fever.

Since many first specimens of blood were inevitably taken after the acute illness had passed,
CFTs on paired sera of ten showed a falling titre, $\overrightarrow{\vec{\omega}}$ and this was the case in $54(39.7 \%)$ of the 1360 showing four-fold changes. Indeed, influenza A듬 was the only virus to give a clear predominances? of rising titres (Table I). (Falling titres, the ma-ه jority having a higher titre of $\leqslant 40$, have not been included as positive results in Tables II and III: ${ }^{\infty}$ see below).

CFT titres of $\geqslant 160$ were obtained on 108 occa- $\overrightarrow{-}$ sions from single specimens, being rare for all viruses except influenza $\mathrm{A}$ and $\boldsymbol{M}$. pneumoniae (Table I). If titres of 80 may be accepted as having a significance comparable with those of $\geqslant 160$, then the pattern of positives alters considerably more than doubling the total and affecting par-o ticularly influenza $C$, respiratory syncytial viruso (RSV), and adenovirus.

\section{CLINICAL RESULTS}

The results of virus tests according to clinical illness are shown in Table II. Positive results include isolations and complement fixation tests showing a four-fold rise in antibody in paired sera or a titre

T A B L E I

RESULTS OF ROUTINE TESTS FOR VIRAL ISOLATION AND COMPLEMENT FIXATION OVER A FIVE-YEAR PERIOD (1967-72) AT THE BROMPTON HOSPITAL

\begin{tabular}{|c|c|c|c|c|c|c|c|c|c|c|c|}
\hline \multirow[b]{3}{*}{ Virus } & \multirow{2}{*}{\multicolumn{2}{|c|}{$\begin{array}{l}\text { Virus Isolation } \\
\text { (599 tests) }\end{array}$}} & \multicolumn{4}{|c|}{ CFT Titre: Paired Sera (393 tests) } & \multicolumn{5}{|c|}{ CFT Titre: Single Specimens ( 1,089 tests) } \\
\hline & & & \multicolumn{2}{|c|}{ 4-fold rise } & \multicolumn{2}{|c|}{ 4-fold fall } & \multicolumn{2}{|c|}{$1 / 80$} & \multicolumn{2}{|c|}{$1 / 160+$} & \\
\hline & No. & $\%$ & No. & $\%$ & No. & $\%$ & No. & $\%$ & No. & $\%$ & \\
\hline \multirow{7}{*}{$\begin{array}{l}\text { Influenza A } \\
\text { Influenza B } \\
\text { Influenza C } \\
\text { Rhinovirus } \\
\text { RSV } \\
\text { Adenovirus } \\
\text { Mycoplasma } \\
\text { Parainfluenza } \\
\text { Coxsackie } \\
\text { Psittacosis } \\
\text { Q fever } \\
\text { Total positives } \\
\text { Total patients } \\
\text { with positives }\end{array}$} & $\begin{array}{r}76 \\
2 \\
-\end{array}$ & $\begin{array}{r}12 \cdot 7 \\
0 \cdot 3 \\
-\end{array}$ & $\begin{array}{r}60 \\
2 \\
2\end{array}$ & $\begin{array}{r}15.3 \\
0.5 \\
0.5\end{array}$ & $\begin{array}{r}18 \\
3 \\
11\end{array}$ & $\begin{array}{l}4 \cdot 6 \\
0 \cdot 8 \\
2 \cdot 8\end{array}$ & $\begin{array}{r}54 \\
2 \\
23\end{array}$ & $\begin{array}{l}5 \cdot 0 \\
0 \cdot 2 \\
2 \cdot 1\end{array}$ & $\begin{array}{r}76 \\
2 \\
5\end{array}$ & $\begin{array}{l}7.0 \\
0.2 \\
0.5\end{array}$ & \\
\hline & $\begin{array}{l}7 \\
3\end{array}$ & $\begin{array}{l}1.2 \\
0.5\end{array}$ & $\frac{-1}{6}$ & $\overline{1.5}$ & $\frac{1}{9}$ & $\overline{2 \cdot 5}$ & $\frac{7}{15}$ & $\overline{1 \cdot 4}$ & - & $\overline{0.6}$ & \\
\hline & $\begin{array}{r}2 \\
12\end{array}$ & $\begin{array}{l}0 \cdot 3 \\
2 \cdot 0\end{array}$ & $\begin{array}{l}1 \\
9\end{array}$ & $\begin{array}{l}0 \cdot 3 \\
2 \cdot 5\end{array}$ & $\begin{array}{l}1 \\
9\end{array}$ & $\begin{array}{l}0 \cdot 3 \\
2 \cdot 5\end{array}$ & $\begin{array}{r}6 \\
10\end{array}$ & $\begin{array}{l}0.6 \\
0.9\end{array}$ & $\overline{11}$ & $\overline{1.0}$ & \\
\hline & 9 & $1 \cdot 2$ & $\overline{-}$ & 二 & $二$ & 二 & 二 & 二 & 2 & $0 \cdot 2$ & \\
\hline & - & - & 2 & 0.5 & 3 & $0 \cdot 8$ & 1 & $\overline{0.1}$ & $\begin{array}{l}1 \\
4\end{array}$ & $\begin{array}{l}0.1 \\
0.4\end{array}$ & \\
\hline & $\overline{118}$ & $\overline{19 \cdot 7}$ & $\overline{82}$ & $\overline{20.5}$ & $\overline{54}$ & $\overline{13.8}$ & $\overline{111}$ & $\overline{10 \cdot 2}$ & $\overline{108}$ & $\overline{9 \cdot 9}$ & \\
\hline & 111 & 18.5 & 78 & $20 \cdot 0$ & 46 & $11 \cdot 7$ & 107 & 9.8 & 100 & $9 \cdot 2$ & \\
\hline
\end{tabular}

iSerology only on request.

T A B L E I I

RESULTS OF VIRUS TESTS ACCORDING TO CLINICAL ILLNESS

\begin{tabular}{|c|c|c|c|c|c|c|c|}
\hline \multirow[t]{2}{*}{ Recent Acute Illness } & \multicolumn{3}{|c|}{ Total } & \multicolumn{2}{|c|}{ Influenza A } & \multicolumn{2}{|c|}{ Other Viruses } \\
\hline & No. & + ve & $\%+v e$ & +ve & $\%+v e$ & $+\mathrm{ve}$ & $\%+v e$ \\
\hline $\begin{array}{l}\text { Influenza-like } \\
\text { Upper respiratory infection } \\
\text { Bronchitis, asthma } \\
\text { Pneumonia }\end{array}$ & $\begin{array}{l}225 \\
126 \\
244 \\
377\end{array}$ & $\begin{array}{l}85 \\
27 \\
50 \\
87\end{array}$ & $\begin{array}{l}38 \cdot 0 \\
22 \cdot 2 \\
20 \cdot 5 \\
23 \cdot 1\end{array}$ & $\begin{array}{l}62 \\
18 \\
38 \\
56\end{array}$ & $\begin{array}{l}27 \cdot 6 \\
15 \cdot 9 \\
15 \cdot 6 \\
14 \cdot 8\end{array}$ & $\begin{array}{r}23 \\
9 \\
12 \\
31\end{array}$ & $\begin{array}{r}10 \cdot 4 \\
6 \cdot 3 \\
4 \cdot 9 \\
8 \cdot 3\end{array}$ \\
\hline $\begin{array}{l}\text { Total } \\
\text { No recent acute illness }\end{array}$ & $\begin{array}{l}972 \\
223\end{array}$ & $\begin{array}{r}249 \\
7\end{array}$ & $\begin{array}{r}25 \cdot 9 \\
3 \cdot 1\end{array}$ & $\begin{array}{r}174 \\
3\end{array}$ & $\begin{array}{r}18 \cdot 5 \\
1 \cdot 3\end{array}$ & $\begin{array}{r}75 \\
4\end{array}$ & $\begin{array}{l}7 \cdot 5 \\
1 \cdot 8\end{array}$ \\
\hline Overall total & 1,195 & 256 & $21 \cdot 5$ & 177 & $14 \cdot 8$ & 79 & $6 \cdot 7$ \\
\hline
\end{tabular}


T A B L E I I I

POSITIVE VIRUS TESTS IN PATIENTS WITH RECENT ACUTE ILLNESSES COMPARED WITH ASSOCIATED CHRONIC PULMONARY DISEASES

\begin{tabular}{|c|c|c|c|c|c|c|c|}
\hline \multirow{2}{*}{$\begin{array}{c}\text { Chronic Pulmonary } \\
\text { Disease }\end{array}$} & \multicolumn{3}{|c|}{ Total } & \multicolumn{2}{|c|}{ Influenza $\mathbf{A}$} & \multicolumn{2}{|c|}{ Other Viruses } \\
\hline & No. & t ve & $\%+$ ve & +ve & $\%+$ ve & +ve & $\%+v e$ \\
\hline $\begin{array}{l}\text { None } \\
\text { Bronchitis } \\
\text { Asthma } \\
\text { Other chronic disease }\end{array}$ & $\begin{array}{l}314 \\
324 \\
195 \\
139\end{array}$ & $\begin{array}{r}123 \\
92 \\
21 \\
13\end{array}$ & $\begin{array}{r}39 \cdot 2 \\
28 \cdot 4 \\
10 \cdot 8 \\
9 \cdot 3\end{array}$ & $\begin{array}{r}69 \\
79 \\
17 \\
9\end{array}$ & $\begin{array}{r}22 \cdot 0 \\
24 \cdot 4 \\
8 \cdot 7 \\
6 \cdot 5\end{array}$ & $\begin{array}{r}54 \\
13 \\
4 \\
4\end{array}$ & $\begin{array}{r}17 \cdot 2 \\
4 \cdot 0 \\
2 \cdot 1 \\
2 \cdot 8\end{array}$ \\
\hline Total & 972 & 249 & $25 \cdot 6$ & 174 & 17.9 & 75 & $7 \cdot 7$ \\
\hline
\end{tabular}

of $\geqslant 160$ in single specimens. There were four mixed infections, influenza A with $\operatorname{RSV}(2)$ and $M$. pneumoniae, and one with $M$. pneumoniae and rhinovirus. Some 223 patients had no recent acute illness; they had a variety of chronic pulmonary diseases, the tests being ordered as part of routine clinical investigation or for purposes of research.

The overall diagnostic rate was $21.5 \%$, rising to $38 \%$ in patients with influenza-like illnesses and falling to $3 \cdot 1 \%$ for patients having had no recent acute illness. One hundred and seventy seven $(69.1 \%)$ of the 256 positives were for influenza $\mathrm{A}$, which included the epidemic of Hong Kong influenza in the winter of 1969-70. At the height of the epidemic in December 1969-January 1970, 189 inpatients with recent acute respiratory illness were tested, of whom $81(42.9 \%)$ were positive (19 isolation, 47 serology, and 15 isolation and serology).

In comparing the results of virus tests following recent acute illness in patients with or without associated chronic pulmonary disease, the 223 patients listed in Table II as having had no recent acute pulmonary illness have been deducted from the original 1195 patients (Table III). The 314 patients with acute but not chronic pulmonary disease, mainly pneumonia and influenza-like illnesses, gave an expectedly high rate of positive results $(39 \cdot 2 \%)$. A figure above average $(28.4 \%)$ was also found in patients with chronic bronchitis and contrasts with the low figure for asthma $(10.8 \%)$. Patients listed as having other chronic diseases included those with pulmonary fibrosis, tuberculosis, and carcinoma and gave a poor yield of positives $(9 \cdot 3 \%)$.

The dominance of influenza $A$ among positive results is linked with the profound effect this virus has upon hospital admissions in the winter months and the ease with which the diagnosis can be made. 1967-68 saw the last wave of Asian influenza. The beginnings of Hong Kong influenza occurred in 1968-69 followed by a major epidemic in 1969-70 (Miller, Pereira, and Clarke, 1971).
There was virtually no influenza in 1970-71 and then the Hong Kong strain appeared sporadically in 1971-72. The monthly Brompton figures for CFT titres of $\geqslant 80$ for influenza A over the fiveyear period are plotted in the Figure. They are compared with mean temperatures at 0900 hours in London, mortality rates from respiratory diseases in the area of the Greater London Council, and hospital admissions for respiratory diseases through the Emergency Bed Service (EBS) from Greater London. The usual seasonal pattern for a non-epidemic winter was seen in 1970-71, when there was a brief cold spell after Christmas. The number of patients admitted to hospital through the EBS with respiratory disease rose by $50 \%$ and the mortality from pneumonia, bronchitis, and influenza rose by $38 \%$ compared with the figures from the preceding summer. The major swings in morbidity and mortality were related to epidemics of influenza $A$. In the Hong Kong influenza of 1969-70, hospital admissions for respiratory diseases were two and a half times and deaths twice those of the previous summer. Indeed, throughout the period there was a general correspondence between the Brompton CFT results and trends in respiratory morbidity and mortality. This relationship applies also to the percentage of positive CFT results obtained. The percentage of all CFT performed during successive Januaries giving titres for influenza A of $\geqslant 80$ were: $30 \%$ (1968), $23 \%$ (1969), $41 \%$ (1970), $3 \%$ (1971), and $14 \%$ (1972).

Twenty-four patients had positive tests for $M$. pneumoniae. Three had asthma and one fibrosing alveolitis; the remaining 20 had no chronic pulmonary disease. Eighteen patients had pneumonia which was attributed to $M$. pneumoniae infection, and two died. Of the nine patients positive for Coxsackie viruses, eight had an influenza-like illness or upper respiratory symptoms. Other manifestations included pneumonia (1), myocarditis (2), pleurisy (2), and meningism (1). Two of five patients with positive tests for psittacosis had been 


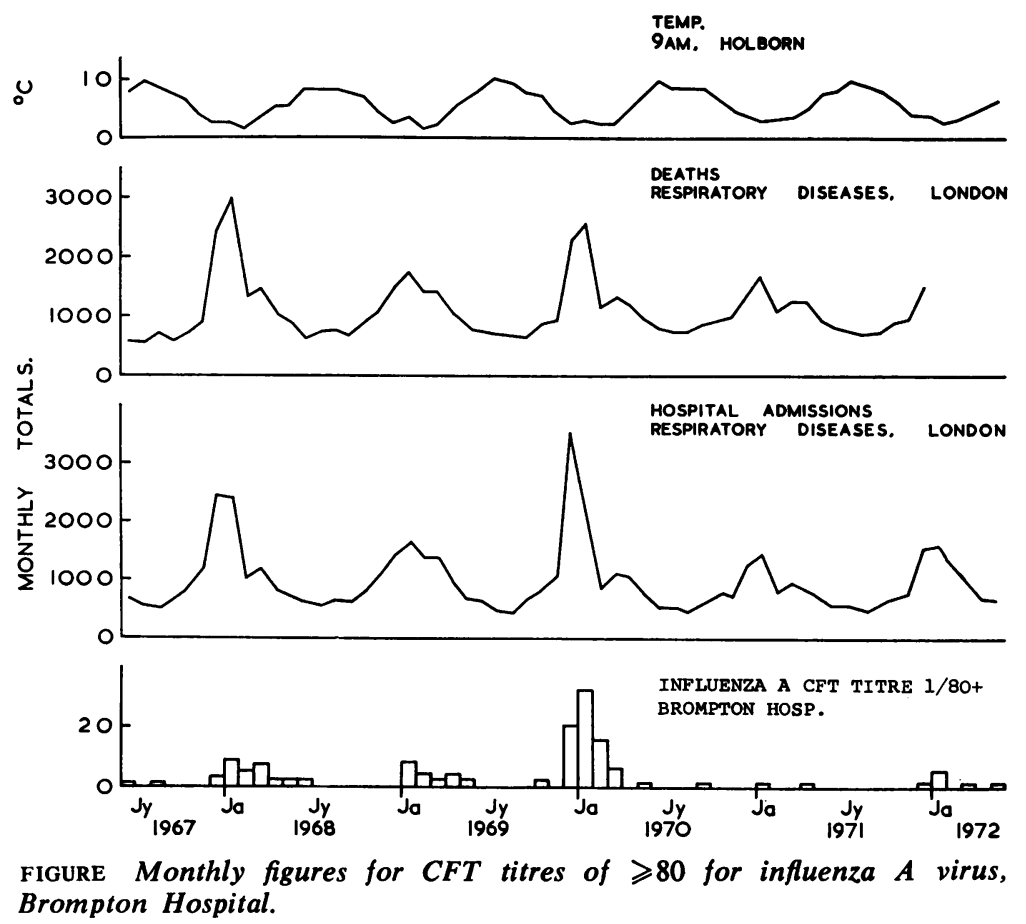

in contact with birds and three were seriously ill with pneumonia. There were no instances of $Q$ fever.

\section{DISCUSSION}

Since the Brompton is a specialist chest hospital there was inevitably selection of patients for admission and variability in the extent to which clinicians availed themselves of the laboratory facilities. However, this study shows that an appreciable number $(21.5 \%)$ of inpatients had recently been infected with respiratory viruses. The overall validity of the tests is confirmed by the high diagnostic rate in patients with recent acute illness $(25.9 \%)$ compared with those without such illness $(3.1 \%)$ (Table II). The results and indeed the choice of test were much influenced by the fact that only $42 \%$ of all patients gave a history of the onset of an acute respiratory illness during the week before admission. This reduced the likelihood of successful viral isolation, particularly of rhinoviruses for which this is the only available diagnostic procedure. Hence, with most specimens being taken after the first week of illness, diagnosis rested mainly upon complement fixation tests, as seen in Tables I and II.
In the 1195 patients, the $256(21.5 \%)$ positive $\overrightarrow{\vec{B}}$ comprised $111(9.3 \%)$ by isolation, $78(6.5 \%)$ bे four-fold rise in titre in paired sera, and 10\% $(8.4 \%)$ by CFT titres of $\geqslant 160$ in single specimens. or the first specimen of paired sera, some patientst being positive to more than one virus. While aco cepting a four-fold rise of titre in paired sera as valid evidence of recent infection, the test was positive in only $6.5 \%$ of the patients and was ordinarily reported long after the acute illness had passed.

In assessing the value of complement fixation tests in single sera, it is unsafe to assume that high titres give more than presumptive evidence of recent infection, since some individuals have persistently high titres for long periods. They are most likely to be diagnostic in infections by influ enza virus and $M$. pneumoniae, against which ant bodies are generally transitory (Heath, 1974). major disadvantage of testing single sera is the some first infections do not stimulate high leve of antibody even in convalescent sera, as was borne out in this series. Of 62 patients with in fluenza $\mathrm{A}$ isolations, $6.5 \%$ of those tested in the first week had titres of $\geqslant 80,50 \%$ in the secong week, and $39 \%$ in the third week.

Single titres of $\leqslant 160$ have sometimes bee 
taken as evidence of recent infection when the clinical features were appropriate and reasonable precautions have been taken to exclude other causes (Biberfeld, Stenbeck, and Johnsson, 1968; Copps et al., 1968; Stallman and Allan, 1970). In this series, titres of $\geqslant 160$ were originally regarded as necessary for diagnosis, but single readings of 80 appeared to carry the same significance, at least for influenza $A$. The outbreaks of influenza $A$ during the five years were clearly defined, the high titres occurring in the winter and spring. Titres of $\geqslant 160$ were found in $76 / 760$ specimens taken during December to May and in 0/329 during June to November, comparable figures for titres of 80 being $49 / 760$ and $5 / 329$. No consistent association between titres of 40 and outbreaks of influenza was discernible. Titres for viruses other than influenza A did not give a sufficiently clear pattern of outbreaks for comparisons to be made between titres of 80 and 160 . If the 107 patients with titres of 80 (Table I) be accepted as showing good evidence of recent infection, the positivity rate rises from $21.5 \%$ to $30.8 \%$ overall, and from $8.4 \%$ to $17 \%$ for titres of $\geqslant 80$ in single specimens. Thus, the results of complement fixation tests on single sera had a considerable influence on the diagnostic rate, but their interpretation in individual patients must take into account prevailing titres in the general population and evidence of a recent acute respiratory illness, thus allowing clinicians to relate results to presenting features rather than to rigid laboratory criteria.

It is now well recognized that respiratory viruses play a significant part in acute exacerbations of chronic bronchitis and of asthma, particularly in children (Lambert and Stern, 1972; Horn and Gregg, 1973). The frequency of virus infections among selected groups of patients with chronic bronchitis has varied from $7 \%$ to $64.3 \%$ (Lamy, Pouthier-Simon, and Debacker-Williame, 1973), with $28.4 \%$ in the present series, but differences in material and methods prevent precise comparisons. Influenza $A$ and para-influenza viruses predominated in most series, except in those few in which rhinoviruses were also sought (McNamara, Phillips, and Williams, 1969). In the present study, adult asthmatics with acute exacerbations gave only $10.8 \%$ positive results compared with $28.4 \%$ for chronic bronchitics. These findings confirm the experience of others, namely that viral infections have rarely been held responsible for exacerbations of asthma (Lambert and Stern, 1972). While many patients with chronic bronchitis were admitted with clear histories of influenza or other recent acute infection, the low figure for asthma may be accounted for partly by the admission of patients with chronic asthma in acute exacerbations which were not infective in origin, and possibly because rhinoviruses, thought to be associated with some of these exacerbations (Horn and Gregg, 1973), cannot be identified by CFT and were no longer being excreted by the time the patients were admitted.

The clinical value of respiratory virology is a matter of some controversy and, at worst, has been described as little more than an academic exercise (Herrman, 1970). However, the early recognition of an outbreak of influenza $A$ is important in that it may lead to attempts to contain the infection by isolation, to an awareness that some patients may develop the acute and sometimes fatal complications of influenza, and possibly to vaccination. Other respiratory agents for which early diagnosis is most desirable include $M$. pneumoniae, psittacosis, and $Q$ fever since positive tests have a direct bearing upon treatment which often prevents protracted illness and at times saves lives. Identification of the remaining respiratory viruses allows of no specific treatment but may assist in the practical management of patients and in the curtailment of further tests when a proved infection will account for the clinical features. Furthermore, routine viral testing has an undoubted place in research, especially in the relationship between virus infections and the initiation and progression of chronic pulmonary disease and possibly in its prevention.

The understandable desire of clinicians for rapid reporting influences their choice of test. Isolations, except for myxoviruses and rhinoviruses, take time, as inevitably do CFTs. on paired sera. CFT titres on single specimens may be diagnostic, are quickly done, and may be repeated at weekly intervals. Since many patients are admitted to hospital after the period of viral excretion has passed, the provision of a regular routine service for CFTs on single and paired specimens would seem to offer the best chance of early diagnosis at the present time. The introduction of more rapid methods of diagnosis, such as immunofluorescence and estimates of IgM and IgG, have now stimulated added interest in the diagnosis of respiratory virus infections and may prove to be of great practical value in the development of specific antiviral chemotherapy.

Our sincere thanks are due to Dr. R. B. Heath, Reader in Virology, St. Bartholomew's Hospital, London, for his interest and invaluable advice. Professor P. J. Lawther and Mr. R. E. Waller kindly 
supplied the data for the Figure. We are grateful to the clinicians at the Brompton Hospital for access to the records of patients, to J. M. Inglis, former virologist at the Brompton Hospital, and for assistance from the Microbiology Department, Brompton Hospital.

\section{REFERENCES}

Andrews, B. E. (1968). Personal communication.

Biberfield, G., Stenbeck, J., and Johnsson, T. (1968). Mycoplasma pneumoniae infection in hospitalized patients with acute respiratory illness. Acta Pathologica et Microbiologica Scandinavica, 74, 287.

Bradstreet, C. M. P. and Taylor, C. E. D. (1962). Technique of complement-fixation test applicable to the diagnosis of virus diseases. Monthly Bulletin of the Ministry of Health and Public Laboratory Service, 21, 96.

Chanock, R. M., Fox, H. H., James, W. D., Gutekunst, R. R., White, R. J., and Senterfit, L. B. (1967). Epidemiology of $M$. pneumoniae infection in military recruits. Annals of the New York Academy of Sciences, 143, 484.

Clyde, W. A. (1964). Mycoplasma species identification based upon growth inhibition by specific antisera. Journal of Immunology, 92, 958.

Copps, S. C., Allen, V. D., Sueltmann, S., and Evans, A. S. (1968). A community outbreak of Mycoplasma pneumonia. Journal of the American Medical Association, 204, 123.

Griffin, J. P. and Crawford, Y. E. (1969). Association of Mycoplasma pneumoniae infection with primary atypical pneumonia. American Review of Respiratory Disease, 100, 206.
Heath, R. B. (1974). Personal communication.

Herrmann, E. C. Jr. (1970). The tragedy of viral diagnosis. Postgraduate Medical Journal, 46, 545. 을

Horn, M. E. C. and Gregg, I. (1973). Role of viral $\stackrel{\bar{\omega}}{\frac{}{\sigma}}$ infection and host factors in acute episodes of $\mathbb{\triangle}$ asthma and chronic bronchitis. Chest, 63, 44S (April supplement).

Lambert, H. P. and Stern, H. (1972). Infective factors $\vec{\circ}$ in exacerbations of bronchitis and asthma.British Medical Journal, 3, 323.

Lamy, M. E., Pouthier-Simon, F., and DebackerWilliame, E. (1973). Respiratory viral infections in hospital patients with chronic bronchitis. $\omega$ Observations during periods of exacerbation and $O$ quiescence. Chest, 63, 336.

McNamara, M. J., Phillips, I. A., and Williams, O. B. (1969). Viral and Mycoplasma pneumoniae infections in exacerbations of chronic lung을 disease. American Review of RespiratoryDisease, 100, 19.

Miller, D. L., Pereira, M. S., and Clarke, M. (1971) فَ Epidemiology of the Hong Kong/68 variant of $\frac{C}{\omega}$ influenza A2 in Britain. British Medical Journal, 1,475 .

Schmidt, N. J., and Lennette, E. H. (1973). Advancesư in the serodiagnosis of viral infections. Progress in Medical Virology, 15, 244.

Stallman, N. D. and Allan, B. C. (1970). A surveyฏ of antibodies to Mycoplasma pneumoniae ino Queensland. Medical Journal of Australia, 1, 800 .

Requests for reprints to: Dr. N. C. Oswald, Brompton Hospital, London SW3 6HP. 